\title{
Underutilized horse chestnut (Aesculus indica) flour and its utilization for the development of
}

\section{gluten-free pasta}

\author{
Syed Insha Rafiq ${ }^{1}$, Khalid Muzaffar ${ }^{2}$, Syed Mansha Rafiq ${ }^{3}$, DC Saxena ${ }^{1 *}$, BN Dar ${ }^{2}$ \\ ${ }^{1}$ Department of Food Engineering and Technology, SLIET, Longowal, Punjab, India; ${ }^{2}$ Department of Food Technology, \\ IUST, Awantipora, India; ${ }^{3}$ Department of Food Science E Technology, NIFTEM Kundli, Sonepat, Haryana, India
}

*Corresponding Authors: DC Saxena, Department of Food Engineering and Technology, SLIET, Longowal, Punjab India. Email: dcsaxena@yahoo.com; BN Dar, Department of Food Technology, IUST, Awantipora, India. Email: darnabi@gmail.com

Received: 11 June 2021; Accepted: 18 September 2021; Published: 7 October 2021

(c) 2021 Codon Publications

OPEN ACCESS (C) $\underset{\mathrm{BY}}{\mathrm{NC}(\mathrm{OA}}$

PAPER

\begin{abstract}
There has been a growing demand for the production of gluten-free products due to increased occurrence of celiac disease. Thus, different research groups have been investigating the use of various available materials for the development of these functional products to fulfill customer's needs. Horse Chestnut (Aesculus indica) seeds are underutilized, low-cost, and gluten-free, found in hilly areas of the Himalayan region of Kashmir valley, India. To determine their potential as an alternative to conventional food grains, an investigation was conducted to determine the physicochemical, functional, pasting, and thermal properties of Horse Chestnut (HCN) flour and its compatibility for the development of gluten-free pasta. HCN flour comprised $73.34 \%$ carbohydrate, $11.36 \%$ protein, $6.34 \%$ crude fiber, $3.27 \%$ fat, $3.16 \%$ ash, $3.15 \mathrm{~g} / \mathrm{g}$ oil absorption capacity, and $4.65 \%$ water absorption index. $\mathrm{HCN}$ flour showed $505 \mathrm{cp}$ peak, $354 \mathrm{cp}$ trough, $151 \mathrm{cp}$ breakdown, $472 \mathrm{cp}$ final viscosity, and $66.05^{\circ} \mathrm{C}$ pasting temperature. Transition temperatures (onset, peak, and conclusion) and enthalpy change $(\Delta \mathrm{H})$ were $60.12^{\circ} \mathrm{C}, 69.90^{\circ} \mathrm{C}$, $81.53^{\circ} \mathrm{C}$, and $10.56 \mathrm{~J} / \mathrm{g}$, respectively. Pasta prepared from $\mathrm{HCN}$ flour using guar gum $(0,0.5$, and $1 \%)$ was analyzed for color, cooking qualities, and textural and sensory analysis. The present results showed that HCN flour possesses good nutritional quality and has properties comparable to conventional wheat flour. Therefore, HCNflour-based pasta can act as a nutritious alternative to conventional gluten-free pasta and add variety to the diet of people suffering from celiac disease.
\end{abstract}

Keywords: celiac disease; cooking; horse chestnut; nonconventional; nutritional; pasta

\section{Introduction}

Horse Chestnut (Aesculus indica) is abundantly found in hilly areas of the Himalayan region of Kashmir valley, India. The seeds of the tree are harvested during October and November. Horse Chestnut ( $\mathrm{HCN})$ seeds are mainly consumed by wild animals and many seeds are wasted. The seeds are kept in running water to reduce the bitterness attributed to the presence of anti-nutrients and then added in powdered form to wheat flour for making Halwa (porridge) and chapattis, a traditional flatbread (Rajeasekaran and Joginder, 2009). HCN seeds can be used as nutritional supplements because they are nutritionally good and have a distinctive composition of carbohydrate, crude protein, fat, and ash. Oleic acid, linoleic acid, palmitic acid, linolenic acid, arachidic acid, and myristic acid are the major fatty acids present in the $\mathrm{HCN}$ seed. The chief minerals present in $\mathrm{HCN}$ include potassium, phosphorus, calcium, sulfur, iron, copper, zinc, and manganese (Majeed et al., 2010). The seeds 
also have several medicinal uses like in the treatment of fever, viral diseases, skin infections, and cardiovascular disorders (Kaur et al., 2011). HCN seeds are rich in polyphenols, flavonoids, fiber, and essential minerals (Majeed et al., 2010).

Pasta, a traditional delicacy, is a popular staple food used throughout the world because of its low cost, longer shelf life, and ease of preparation. Commonly, wheat flour is used in the preparation of pasta (Kaur et al., 2012). Pasta food products are produced by extruding feed mixture in an extruder equipped with different dyes that determine the shape of the final product. The pasta products are then dried and packed. It has been recognized as an ancient means of nourishment and versatile food from nutritive and gastronomic perspectives (Fuad and Prabhasankar, 2010). Pasta is considered a superior medium for the incorporation of nutrients as per the reports of Food and Drug Administration and World Health Organization (Pasqualone et al., 2016). The selection of flour for pasta development depends on water absorption and water solubility indexes and the acceptability and cooking parameters of the developed pasta (Rudra et al., 2020). The behavior of starch and protein in pasta during cooking is such that starch swells and solubilizes but protein gets coagulated during cooking (Hager et al., 2012). Best-quality pasta has acceptable firmness with low solid loss, and stickiness (Phongthai et al., 2017). Gluten as the structure builder promotes viscosity, elasticity, extensibility, and cohesiveness in pasta products (Lazaridou et al., 2007). Gluten helps to maintain the shape of bakery products and pasta due to the extensibility and elastic dough behavior with resilience and textural properties acceptable to consumers (Phongthai et al., 2017). However, due to the amplified dominance of celiac disease and other health issues such as gluten allergy, nonceliac gluten sensitivity, and other gluten-related disorders, demand for gluten-free pasta products has increased (Dib et al., 2018; Ozgoren and Yapar, 2019). To avoid these disorders, grains other than wheat may be used, either individually or in combined formulation, to replace gluten in food products. The only possible treatment for individuals having celiac disease is to consume foods devoid of gluten (Witczak et al., 2017). However, gluten-free products have low nutritional quality, and defective textural and sensory property due to crumbly and fragile dough formation (Cai et al., 2016). Hence, to counterbalance the absence of gluten, fortification with gums, proteins, and different flours are considered (Foschia et al., 2017; Padalino et al., 2016). To replace gluten and to maintain the dough structure and texture of the final product, various types of protein and hydrocolloids are used in gluten-free products (Foschia et al., 2017). Hydrocolloids, such as xanthan gum, guar gum, hydroxypropyl methylcellulose, and carboxymethyl cellulose used as an addictive in gluten free products can improve their textural characteristics (Lorenzo et al., 2018; Palavecino et al., 2017). To improve the quality attributes like mouthfeel, texture, consumer acceptability, and shelf-life of gluten-free products, diverse research has been done using alternative components like hydrocolloids, emulsifiers, starches, and nongluten proteins (Capriles et al., 2016; Kumar et al., 2019). The worldwide market for gluten-free food products increased up to $83 \%$ with an estimated annual growth rate of $12.3 \%$ for pasta products until 2022 (Chauvin, 2019). Gluten-free products are not only consumed by celiac patients but also by other individuals as well (Bresciani et al., 2021). Researchers have been motivated by United Nations for the Agenda 2030 to research healthy formulations for bakery and pasta products and the use of functional agro-industrial by-products for fortification in foods (Simonato, 2021).

Because of its good nutritional profile and gluten-free nature, HCN flour may represent a potential nonconventional alternative to conventional flours. Only limited information is available regarding $\mathrm{HCN}$ flour and there are no reports about the production of gluten-free pasta from $\mathrm{HCN}$ four. Therefore, it is essential to characterize the flour to explore possible utilization in food industry and to optimize the ingredients for the development of quality pasta from HCN flour. So, in the present study, characterization of HCN flour with respect to physicochemical, functional, thermal, and pasting properties, and development and characterization of pasta were carried out.

\section{Materials and Methods}

\section{Raw materials}

Fully matured Horse Chestnut seeds were obtained from Horse chestnut trees located at Anantnag, Jammu \& Kashmir, India, cleaned and stored at $5^{\circ} \mathrm{C}$ till used. Hard wheat was procured from Punjab Agriculture University (Ludhiana). The chemicals and reagents were procured from Sigma-Aldrich.

\section{Flour preparation}

Horse Chestnut flour was prepared with slight modification to the method of Singh et al. (2013). The kernels obtained after manual dehulling of $\mathrm{HCN}$ seeds were sliced and then dried in a tray dryer at $60^{\circ} \mathrm{C}$. The slices before drying were treated to reduce the anti-nutritional factors in the previous work of RAFIQ et al. (2016). The dried seed slices were ground in a laboratory-type grinder to obtain $\mathrm{HCN}$ flour. Both wheat and $\mathrm{HCN}$ flours were sieved using a 60-mesh sieve. HCN and wheat flour were then analyzed for various properties. 


\section{Physicochemical characteristics of HCN flour}

\section{Color analysis}

Flour color analysis was done in triplicates, with Color Flex Spectro-colorimeter (D-25, Ruston, USA), and color values $\left(\mathrm{L}^{*}, \mathrm{a}^{*}\right.$, and $\left.\mathrm{b}^{*}\right)$ were determined.

\section{Proximate analysis}

Standard methods were employed to analyze the flour samples for moisture, protein, ash, fiber, and fat content (AOAC, 2006), while the carbohydrate content was determined using the difference method.

\section{Bulk density}

An accurately weighed sample was poured into a graduated cylinder. Tapping during the filling was done for uniform packing. Bulk density was calculated using the below equation:

$$
\text { Bulk density }\left(\mathrm{g} / \mathrm{cm}^{3}\right)=\frac{\text { Weight of the sample }(\mathrm{g})}{\text { Volume of sample }\left(\mathrm{cm}^{3}\right)}
$$

\section{True density}

The method followed by Raigar and Mishra (2015) was used to determine true density. An accurately weighed flour sample ( $1 \mathrm{~g}$ ) was taken and poured into a burette filled with toluene. The equation given below was used to calculate true density:

$$
\text { Truedensity }\left(\mathrm{g} / \mathrm{cm}^{3}\right)=\frac{\text { Weight of flour sample }(\mathrm{g})}{\text { Rise in toluene level }\left(\mathrm{cm}^{3}\right)}
$$

\section{Functional properties}

\section{Water absorption capacity}

Water absorption capacity (WAC) of the flour was determined per Vázquez-Luna et al. (2019) with slight modifications. Approximately, $5 \mathrm{~g}$ of the sample was mixed with $70 \mathrm{~mL}$ of water for $1 \mathrm{~min}$ and then held at room temperature for $30 \mathrm{~min}$, followed by centrifugation $(3000 \times \mathrm{g}$ for $15 \mathrm{~min})$. After centrifugation, the sediment obtained was weighed and WAC was calculated:

$$
\text { WAC }(g / g)=\frac{\text { Weight of se dim ent }}{\text { Weight of flour sample }}
$$

\section{Oil absorption capacity}

The method followed by Khan and Saini (2016) was used to determine the oil absorption capacity (OAC) of the sample. Five grams of flour and $75 \mathrm{~mL}$ of oil were mixed and agitated for $30 \mathrm{~min}$ and then centrifuged for $10 \mathrm{~min}$ at $3000 \times$ g. Afterward, oil was drained while the retained sample was weighed to calculate $\mathrm{OAC}$ as shown in the below equation:

$$
\text { OAC }(\mathrm{g} / \mathrm{g})=\frac{\text { Weight of residue }}{\text { Sample weight }}
$$

\section{Emulsion properties}

The emulsion activity and stability of samples were calculated by using the method of Du et al. (2014). Sample $(3.5 \mathrm{~g})$ and water $(50 \mathrm{~mL})$ were agitated for $30 \mathrm{~s}$ using the high setting homogenizer (Yorco, India). Afterward, groundnut oil $(25 \mathrm{~mL})$ was added and then again homogenized for $30 \mathrm{~s}$, followed by another addition of $25 \mathrm{~mL}$ groundnut oil and then homogenized for $90 \mathrm{~s}$. The emulsion obtained was then centrifuged for $5 \mathrm{~min}$ at $1100 \times \mathrm{g}$.

Emulsion activity (\%)

$$
=\frac{\text { Volume of emulsified layer }}{\text { Emulsion volume beforecentrifugation }} \times \text { Emu }
$$

After calculating the emulsion activity, emulsion stability was evaluated by heating the flour emulsion samples $\left(15 \mathrm{~min}\right.$ at $\left.85^{\circ} \mathrm{C}\right)$, then cooling, followed by centrifugation for $5 \mathrm{~min}$ at $1100 \times \mathrm{g}$. The percent emulsion activity that remained after heating can be expressed as the emulsion stability.

\section{Foaming properties}

The foaming properties, viz., foaming capacity (FC) and foaming stability (FS), were observed with minor modifications to the method followed by Jia et al. (2021). Sample (3 g) and distilled water $(50 \mathrm{~mL})$ were mixed, and the dispersion was homogenized for 3-5 min. The mixture was then instantly poured into the measuring cylinder and the increase in volume percent upon whipping was calculated. The percentage of volume increase was the foaming capacity and the change in the foam volume after $1 \mathrm{~h}$ of storage was recorded as the foaming stability.

FC and FS were calculated using the below mentioned formulas:

$$
\begin{aligned}
& F C(\%)=\frac{V_{2}-V_{1}}{V_{2}} \times 100 \\
& F S(\%)=\frac{V_{3}}{V_{2}-V_{1}} \times 100
\end{aligned}
$$

where, $\mathrm{V}_{1}$ = volume prior to whipping $(\mathrm{mL})$,

$\mathrm{V}_{2}$ = foam volume after whipping $(\mathrm{mL})$, and

$\mathrm{V}_{3}$ = foam volume $(\mathrm{mL})$ after holding

Least gelation concentration (LGC)

The method of Khan and Saini (2016) was used to determine the gelation properties of the flour samples. Two 
percent, 4, 6, 8, 10,12, 14, 16, 18, and 20\% (w/v) of flour suspensions in $5 \mathrm{~mL}$ of water were boiled for $1 \mathrm{~h}$, cooled in cold water, and kept at $4^{\circ} \mathrm{C}$ for $2 \mathrm{~h}$.

\section{Pasting characteristics}

Rapid Visco Analyzer (TecMaster, Warriewood, Australia) was used for the determination of the pasting profile. A programmed heating and cooling cycle (taking sample $3 \mathrm{~g}, 14 \% \mathrm{mb}$; and distilled water $25 \mathrm{~mL}$ ) was used for generating the viscosity profile. Experimental conditions include holding the samples for $1 \mathrm{~min}$ at $50^{\circ} \mathrm{C}$, heating to $95^{\circ} \mathrm{C}$ at $12^{\circ} \mathrm{C} / \mathrm{min}$ cooling rate, holding for $2.5 \mathrm{~min}$ at $95^{\circ} \mathrm{C}$ ), cooling to 95 to $50^{\circ} \mathrm{C}$ at $12^{\circ} \mathrm{C} / \mathrm{min}$ heating rate, and then holding for $2 \mathrm{~min}$ at $50^{\circ} \mathrm{C}$.

\section{Thermal properties}

A differential scanning calorimeter (DSC821, Mettler Toledo, Switzerland) was involved in determining thermal properties of the sample. The samples were prepared with flour (3mg, dwb) and water $(7 \mu \mathrm{l})$, sealed, and kept undisturbed at room temperature for $1 \mathrm{~h}$. The sample was heated at $20-120^{\circ} \mathrm{C}$ at a rate of $10^{\circ} \mathrm{C} / \mathrm{min}$.

\section{Pasta preparation}

Different pasta formulations (control sample (durum wheat); native sample ( $\mathrm{HCN}$ flour $+0 \%$ gum); pasta formulation containing $\mathrm{HCN}$ flour and 0.5 and $1 \%$ guar gum, respectively) were mixed using Hobart benchtop mixer (5KPM50, USA) for $1 \mathrm{~min}$ at low speed followed by conditioning for $5 \mathrm{~min}$ with distilled water $(30 \mathrm{~mL})$. The sample was fed to a single screw extruder (Model: Dolly La Monferrina Italy) of $7 \mathrm{~mm}$ die diameter. Pasta was then transferred to cabinet drier for $4 \mathrm{~h}$ set at $60^{\circ} \mathrm{C}$, reducing the moisture content to $8 \%$, and then packed in high-density polyethylene pouches.

\section{Characterization of pasta}

\section{Color parameters}

Color parameters of pasta were determined using a color spectrophotometer (CM-3600d, Konica Minolta, Bremen, Germany). Color analysis was done in terms of $\mathrm{L}^{*}$, $\mathrm{a}^{*}$, and $\mathrm{b}^{*}$ values.

\section{Cooking properties}

Cooking time was evaluated by using the AACC (2000) method. Pasta sample (10 g) was cooked in water (300 $\mathrm{mL}$ ). The optimum time of cooking is the point of disappearance of the inner white core of pasta and was observed by squeezing the pasta between glass plates. The weight of the cooked pasta after being drained for 2 min was taken as the cooked weight (g). The cooking loss was calculated by evaporation of cooking water to dryness at $110^{\circ} \mathrm{C}$ overnight.

\section{Water uptake}

Water uptake is the difference between the weight of cooked and uncooked samples, and is expressed as uncooked pasta weight percentage (Çabuk and Yilmaz, 2020). The investigation indicated the absorption of water during the cooking process.

\section{Cooking loss}

The method followed by Teterycz et al. (2020) was employed for cooking loss determination. Sample (10 g) was cooked in boiling water $(300 \mathrm{~mL})$ and then cooking water was dried overnight $\left(105^{\circ} \mathrm{C}\right)$. The residue left after drying was weighed and then cooking loss was calculated.

Texture

For determination of texture, the samples were cooked till optimum cooking time, and then drained with 10 min rest time. Four pasta strands were taken and placed under the compression plate of pasta firmness/stickiness rig. The resulting force-time curve was used to determine firmness, cohesiveness, springiness, adhesiveness, chewiness, and gumminess.

\section{Sensory evaluation}

Panel comprising 12 trained members have done the sensory evaluation of pasta samples; evaluated the attributes like firmness, slipperiness, chewiness, surface adhesiveness, appearance; and determined the total score for each pasta sample. Perceived intensities were scored on a 5 -point scale.

\section{Statistical analysis}

The experimental data was statistically analyzed by Oneway ANOVA using triplicate readings for all experiments except sensory evaluation where 12 observations were averaged.

\section{Results and Discussion}

\section{Physiochemical properties of HCN flour}

The desired color characteristics for the flour are low chroma $\left(\mathrm{a}^{*}\right)$ value and high lightness $\left(\mathrm{L}^{*}\right)$ value to meet the consumer preference. The color parameters and nutritional composition of $\mathrm{HCN}$ and wheat flour are given in Table 1. Results showed that the $\mathrm{L}^{*}$ value of the flours was almost similar; however, significant difference 
Table 1. Physicochemical characteristics.

\begin{tabular}{lcc} 
Physicochemical & Horse Chestnut flour & Wheat flour \\
\hline Color & & \\
$\mathrm{L}^{*}$ & $92.07 \pm 0.49^{\mathrm{a}}$ & $92.85 \pm 0.28^{\mathrm{a}}$ \\
$\mathrm{a}^{*}$ & $3.47 \pm 0.21^{\mathrm{a}}$ & $2.03 \pm 0.07^{\mathrm{b}}$ \\
$\mathrm{b}^{*}$ & $13.70 \pm 0.26^{\mathrm{a}}$ & $9.69 \pm 0.15^{\mathrm{b}}$ \\
Moisture content (\%) & $9.71 \pm 1.23^{\mathrm{b}}$ & $11.35 \pm 0.54^{\mathrm{a}}$ \\
Protein (\%) & $7.78 \pm 1.19^{\mathrm{b}}$ & $11.36 \pm 1.10^{\mathrm{a}}$ \\
Crude fat (\%) & $3.27 \pm 0.39^{\mathrm{a}}$ & $1.40 \pm 0.57^{\mathrm{b}}$ \\
Crude fiber (\%) & $6.34 \pm 0.22^{\mathrm{a}}$ & $1.67 \pm 0.14^{\mathrm{b}}$ \\
Ash (\%) & $3.16 \pm 0.05^{\mathrm{a}}$ & $0.88 \pm 0.03^{\mathrm{b}}$ \\
Carbohydrate (\%) & $69.74^{\mathrm{b}}$ & $73.34^{\mathrm{a}}$ \\
Energy value (Cal/100g) & $327.51^{\mathrm{b}}$ & $346.84^{\mathrm{a}}$ \\
Bulk density (g/mL) & $0.64 \pm 0.12^{\mathrm{a}}$ & $0.51 \pm 0.10^{\mathrm{a}}$ \\
True density (g/mL) & $1.25 \pm 0.24^{\mathrm{a}}$ & $1.42 \pm 0.12^{\mathrm{a}}$ \\
\hline
\end{tabular}

Results presented are mean values and the superscripts significantly differ in row $(P<0.05)$.

was observed in a" and b" values. This variation in the color parameters may be ascribed to a difference in the natural pigment content inherent to $\mathrm{HCN}$ and wheat flours depending on the origin of the plant (Drakos et al., 2017). Nutritional composition of $\mathrm{HCN}$ and wheat flour also varied significantly (Table 1 ). Moisture content of HCN flour was low (9.71\%) compared to wheat flour (11.35\%). Similarly, protein and carbohydrate content of $\mathrm{HCN}$ flour was lower than wheat flour. However, HCN flour showed significantly higher values for ash, fat, and crude fiber content than wheat flour. High ash content of $\mathrm{HCN}$ flour could be related to high mineral content of the $\mathrm{HCN}$ seeds being rich in nitrogen, potassium, phosphorus, sulfur, calcium, iron, etc. (Majeed et al., 2010). The bulk density did not differ significantly in both the flours (Table 1). Similar results were observed for the true density of $\mathrm{HCN}$ flour $(1.25 \mathrm{~g} / \mathrm{mL})$ and wheat flour $(1.42 \mathrm{~g} / \mathrm{mL})$.

\section{Functional properties of HCN flour}

\section{Water absorption capacity}

WAC describes the interaction of flour and water under a limited quantity of water. The WAC of flour plays a significant part in food research as it affects other determining properties of food material. $\mathrm{HCN}$ flour showed significantly lower values of WAC, $2.21 \mathrm{~g} / \mathrm{g}$ as compared to wheat flour, $4.65 \mathrm{~g} / \mathrm{g}$ (Table 2). Hydrophilic behavior and gel-forming ability of starch, and protein quality are the determining factors that affect the WAC of flour (Al-Farga et al., 2016). Higher number of hydrophilic components in flour is responsible for its elevated WAC (Njintang et al., 2008). The variation in the WAC
Table 2. Functional characteristics.

\begin{tabular}{lrr} 
Properties & HCN flour & Wheat flour \\
\hline WAC $(\mathrm{g} / \mathrm{g})$ & $2.22 \pm 0.12^{\mathrm{b}}$ & $4.65 \pm 0.08^{\mathrm{a}}$ \\
OAC $(\mathrm{g} / \mathrm{g})$ & $3.24 \pm 0.15^{\mathrm{a}}$ & $1.10 \pm 0.05^{\mathrm{b}}$ \\
Foaming capacity (\%) & $20.2 \pm 1.17^{\mathrm{b}}$ & $31.40 \pm 0.71^{\mathrm{a}}$ \\
Foaming stability (\%) & $22.32 \pm 2.41^{\mathrm{b}}$ & $54.05 \pm 5.52^{\mathrm{a}}$ \\
Emulsion activity (\%) & $58.69 \pm 0.31^{\mathrm{b}}$ & $61.01 \pm 1.33^{\mathrm{a}}$ \\
Emulsion stability (\%) & $62 \pm 0.27^{\mathrm{b}}$ & $68.32 \pm 0.12^{\mathrm{a}}$ \\
\hline
\end{tabular}

WAC, Water absorption capacity; OAC, Oil absorption capacity. Results presented are mean values and the superscripts significantly differ in row $(P<0.05)$.

behavior of the flours could be related to difference in the composition of the flour.

\section{Oil absorption capacity}

OAC capacity is an important property of the flour, which defines its application in various food formulations and determines its capacity to entrap oil which affects flavor retention and mouthfeel of the developed product (Khattab and Arntfield, 2009). OAC of flour is important for new product development and storage stability. Significantly higher values of OAC of $3.15 \mathrm{~g} / \mathrm{g}$ in $\mathrm{HCN}$ flour than $1.10 \mathrm{~g} / \mathrm{g}$ in wheat flour was observed (Table 2). Interaction of nonpolar side chains present in the flour with oil through hydrocarbon side chains affect their OAC (Adebowale and Lawal, 2004). Flour particle size, starch content, and occurrence of nonpolar amino acids are other factors that affect the OAC of flour (Chau et al., 1997; Ofori et al., 2020). Also, the protein type and content contribute to oil-retaining properties of the foods (Ravi and Sushelamma, 2005).

\section{Foaming properties}

The foaming properties are essential parameters for the formulation of food products. Results related to foaming capacity and stability of $\mathrm{HCN}$, and wheat flour is given in Table 2. Carbohydrate and protein content play an important role in determining the foaming properties of flour (Sreerama et al., 2012). Formation of interfacial layer by proteins is responsible for foaming, keeps air bubbles in suspension, and slows down coalescence rate (Adebowale and Lawal, 2004). HCN flour and wheat flour showed foaming capacity of 20.20 and $31.40 \%$, respectively. Low-protein and high-fat content of $\mathrm{HCN}$ flour is responsible for lower foaming capacity of $\mathrm{HCN}$ flour (Siddiq et al., 2010). Formation of the protein-fat complex may influence the foaming properties. Foam stability for Horse Chestnut flour (22.32\%) was also lower than wheat flour (54.05\%). Good foam stability is most likely associated with soluble proteins' surface activity 
in continuous water phase while the presence of highly ordered globular proteins in the flour which resist surface denaturation could be related to low foamability (Du et al., 2014).

\section{Emulsion properties}

The ability of protein to form a stable emulsion is known as emulsion activity, and it gives information about the ability of protein to occupy the interfacial layer of oilwater emulsion while the emulsion stability is related to the strength of an emulsion to stress, provided by the proteins (Singh et al., 2010). Emulsion capacity and stability values of $\mathrm{HCN}$ and wheat flour are significantly different (Table 2). Emulsion activity and stability of $\mathrm{HCN}$ flour was lower (58.69 and 62\%) than wheat flour (61.01 and $67.87 \%$ ), which might be related to the difference in quality and content of protein. Proteins having several polar side chains make them more hydrophilic, thereby increasing the protein-water interactions, and thus affecting their emulsification properties (Yan et al., 2020). The high emulsion stability depends on the globular nature of proteins in the flour. The emulsifying properties of different foods vary due to varied composition and processing conditions and the capacity of protein to form and stabilize emulsions (Adebowale et al., 2005).

\section{Least gelation concentration}

LGC is expressed as the quantity of flour required per volume to obtain a gel. Results related to LGC of flour samples are presented in Table 3. Flour which has lower value of LGC has greater ability to form gels and low concentration of flour is required for gel formation. Higher concentration $(6 \mathrm{~g} / 100 \mathrm{~mL})$ of $\mathrm{HCN}$ flour was required for initial gel formation than wheat flour $(4 \mathrm{~g} / 100 \mathrm{~mL})$. A firm gel was obtained when using $12 \%$ of $\mathrm{HCN}$ flour and $10 \%$ of wheat. The difference in the gel-forming ability among various types of flours is related to different ratios of components like carbohydrates, proteins, and lipids (Drakos et al., 2017). The lower LGC value of wheat flour might be related to high protein and starch content, which are responsible for gel formation (Joshi et al., 2015).

\section{Pasting characteristics}

Pasting profile of wheat and $\mathrm{HCN}$ flour is depicted in Figure 1. Pasting properties play a significant part in the selection of raw materials for industrial use as a thickener, binder, etc. Rigidity of starch granules which affects swelling of starch granules and leaching of amylose in solution determine the pasting properties of the flour (Leewatchararongjaroen and Anuntagool, 2016). Compared to wheat flour (pasting temperature: $83.36^{\circ} \mathrm{C}$ ), the pasting temperature of $\mathrm{HCN}$ flour was low $\left(66.05^{\circ} \mathrm{C}\right)$. It could be the starch in $\mathrm{HCN}$ flour that is less resistant
Table 3. Least gelation concentration.

\begin{tabular}{lll} 
Concentration & HCN Gel & Wheat Gel \\
\hline $2 \%$ & No & No \\
$4 \%$ & No & Weak \\
$6 \%$ & Weak & Weak \\
$8 \%$ & Weak & Weak \\
$10 \%$ & Weak & Firm \\
$12 \%$ & Firm & Firm \\
$14 \%$ & Firm & Firm \\
$16 \%$ & Firm & Hard \\
$18 \%$ & Hard & Hard \\
$20 \%$ & Hard & Hard \\
\hline
\end{tabular}

to swelling that is responsible for the low PT of Horse Chestnut flour. The pasting temperature has also been related to the amount of protein present. Shevkani et al. (2015) have reported high pasting temperature with higher amount of protein in rice flour. Peak viscosity (PV) which indicates the degree of granule swelling was 505 $\mathrm{cP}$ for $\mathrm{HCN}$ flour and $1215 \mathrm{cP}$ for wheat flour. The low peak viscosity could be due to high fat content in $\mathrm{HCN}$ flour that produces more fluid system and subsequently low viscosity. Trough viscosity was $354 \mathrm{cP}$ ( $\mathrm{HCN}$ flour) and $1005 \mathrm{cP}$ (wheat flour) and depicts a decline following PV owing to swollen starch granules disruption upon high temperature and shear. Breakdown viscosity was $151 \mathrm{cp}$ for HCN flour and $210 \mathrm{cp}$ for wheat flour. The low breakdown viscosity indicates higher resistance to shearing at high temperature. Final viscosity (FV) was $472 \mathrm{cP}$ for $\mathrm{HCN}$ flour and $1560 \mathrm{cP}$ for wheat flour. Besides this, setback viscosity (SBV) of HCN flour (118 cp) was considerably lower than that of wheat flour (301 cP). The important factors that affect setback and final viscosities are polymerization or reordering of leached amylose and linear amylopectin (Abu et al., 2006). The difference in pasting parameters of the flours could be linked to the occurrence of components such as proteins, minerals, lipids, etc., which can bind with starch, thereby affecting the pasting parameters of the flour (Ocheme et al., 2018). The protein and lipid components of the flour affect the pasting properties through amylose-protein and amylose-lipid interactions (Yu et al., 2012). Due to the protective effect of protein molecules on the integrity of starch granules, viscosity of corn starch paste decreased (Singh et al., 2014). Difference in the viscosity of wheat flour pastes is correlated to variation in the proportion of polymeric or monomeric proteins among wheat flours (Singh et al., 2016).

\section{Thermal properties of HCN flour}

Thermal properties are related to gelatinization behavior described as granular disruption, loss of 


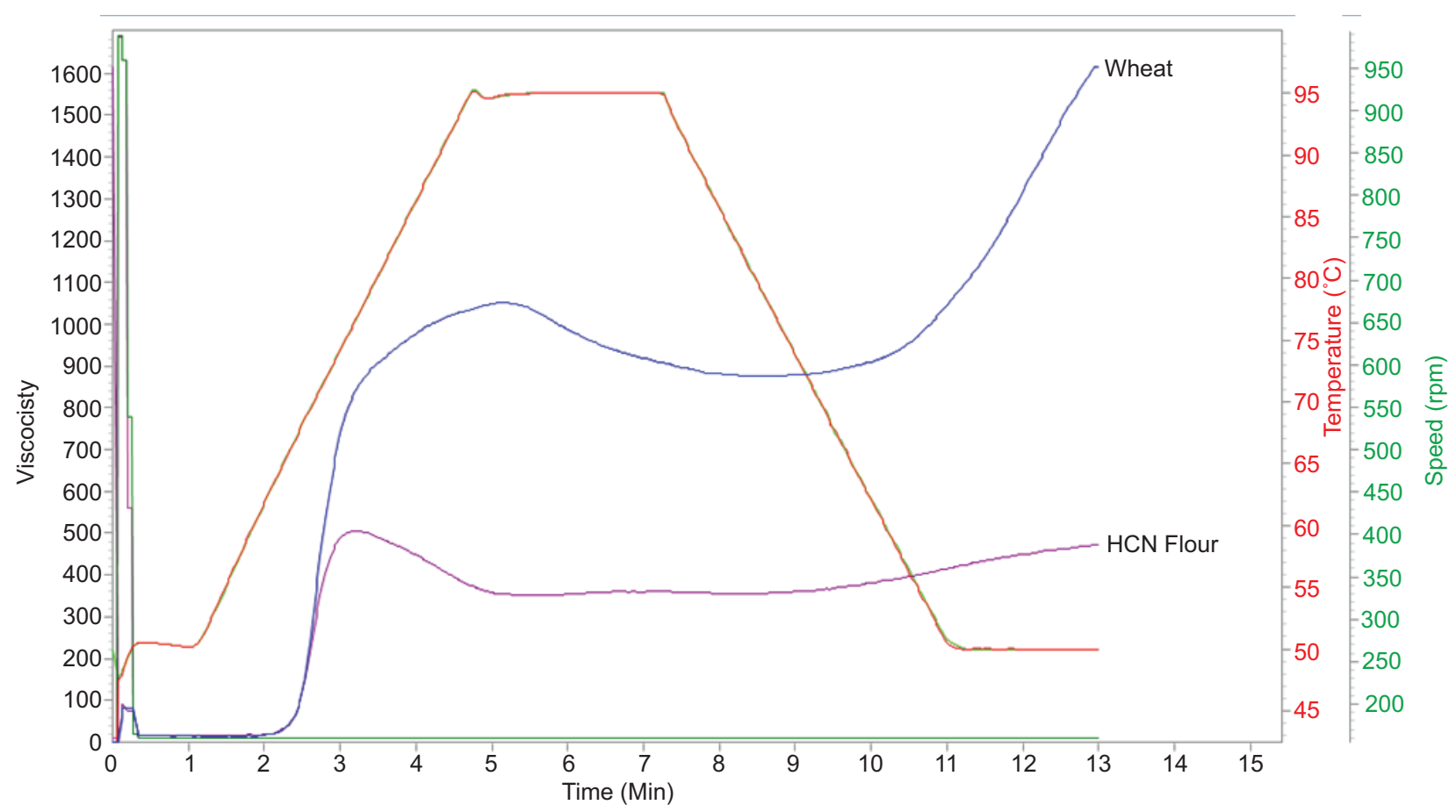

Figure 1. Pasting profile of wheat and HCN flour.

double helical and crystalline structure of starch (Rincón-Londoño et al., 2016). Table 4 shows the results related to onset, peak, and conclusion temperatures, and enthalpy of gelatinization $(\Delta \mathrm{H})$ of $\mathrm{HCN}$ and wheat flour. Transition temperatures for $\mathrm{HCN}$ flour were $\mathrm{T}_{\mathrm{o}}=60.12$, $\mathrm{T}_{\mathrm{p}}=69.90$, and $\mathrm{T}_{\mathrm{c}}=81.53{ }^{\circ} \mathrm{C}$ ) while for wheat flour transition temperatures were high $\left(\mathrm{T}_{\mathrm{o}}=78.32, \mathrm{~T}_{\mathrm{p}}=81.12\right.$, and $\left.\mathrm{T}_{\mathrm{c}}=86.34^{\circ} \mathrm{C}\right)$. Starch granule size, their form and distribution, and the bonding between micellar network of the granule and other flour components are responsible for variation in transition temperatures of flours (Xu et al., 2019). Enthalpy of gelatinization of $10.56 \mathrm{~J} / \mathrm{g}$ was observed for $\mathrm{HCN}$ flour while for wheat flour, it was 13.21 $\mathrm{J} / \mathrm{g}$. Variation in the shape of starch granules, and proportion of large and small granules are the factors that affect the enthalpy of gelatinization (Kaur and Singh, 2005). The decreased gelatinization enthalpy can also be due to the disruption of crystalline regions upon depolymerization of amylose and breakdown of amylopectin.

\section{Color characteristics of pasta}

Customer acceptance depends on the color of the product and the most desirable attribute of pasta quality is the bright yellow color (Petitot et al., 2010). Color values (L*, $\mathrm{a}^{*}$, and $\mathrm{b}^{*}$ ) of raw and cooked Horse Chestnut pasta, and control were significantly different (Table 5 ). The $L^{*}$ value for Horse Chestnut pasta was less than the control pasta sample. The differences in color parameters between
Table 4. Thermal characteristics.

\begin{tabular}{lcc} 
Parameters & Horse Chestnut flour & Wheat flour \\
\hline Onset Temp. $\left({ }^{\circ} \mathrm{C}\right)$ & $60.12 \pm 0.11^{\mathrm{b}}$ & $78.32 \pm 0.98^{\mathrm{a}}$ \\
Peak Temp. $\left({ }^{\circ} \mathrm{C}\right)$ & $69.90 \pm 0.23^{\mathrm{b}}$ & $81.12 \pm 0.12^{\mathrm{a}}$ \\
Conclusion Temp. $\left({ }^{\circ} \mathrm{C}\right)$ & $81.53 \pm 0.17^{\mathrm{b}}$ & $86.34 \pm 0.18^{\mathrm{a}}$ \\
$\Delta \mathrm{H}(\mathrm{J} / \mathrm{g})$ & $10.56 \pm 0.41^{\mathrm{b}}$ & $13.21 \pm 0.63^{\mathrm{a}}$ \\
\hline
\end{tabular}

Results presented are mean values and the superscripts significantly differ in row $(P<0.05)$.

control and HCN pasta samples could be related to the inherent color of the flour and the pigments present. The addition of gum in pasta formulation at different levels showed no significant effect on pasta color. Similar effect of hydrocolloids on color characteristics of developed noodles was observed by Shere et al. (2020) Color values of cooked and uncooked pasta were significantly different which could be related to the leaching of pigments on cooking.

\section{Cooking characteristics of pasta}

The cooking characteristics of pasta are influenced by numerous phenomena taking place during cooking, viz., hydration, starch gelatinization, and interaction with nonstarchy constituents. Cooking parameters for the pasta samples including cooked weight, water uptake, solid loss, and cooking time are given in Table 6 . The 
Table 5. Color characteristics of raw and cooked pasta

\begin{tabular}{|c|c|c|c|c|c|c|}
\hline \multirow[t]{2}{*}{ Sample } & \multicolumn{3}{|c|}{ Raw pasta } & \multicolumn{3}{|c|}{ Cooked Pasta } \\
\hline & $L^{*}$ & $a^{*}$ & $b^{*}$ & $L^{*}$ & $a^{*}$ & $\mathbf{b}^{*}$ \\
\hline A & $75.40 \pm 2.05^{a}$ & $1.30 \pm 0.34^{b}$ & $20.73 \pm 1.2^{\mathrm{a}}$ & $70.60 \pm 1.68^{a}$ & $0.04 \pm 0.01^{a}$ & $19.34 \pm 0.76^{a}$ \\
\hline B & $62.85 \pm 1.36^{b}$ & $1.49 \pm 0.40^{\mathrm{a}}$ & $18.09 \pm 1.83^{b}$ & $55.84 \pm 1.46^{b}$ & $0.04 \pm 0.03^{a}$ & $16.10 \pm 0.70^{b}$ \\
\hline C & $61.41 \pm 1.90^{b}$ & $1.35 \pm 0.32^{b}$ & $17.49 \pm 1.31^{c}$ & $56.17 \pm 2.01^{b}$ & $0.03 \pm 0.03^{a}$ & $15.50 \pm 0.72^{\circ}$ \\
\hline D & $61.82 \pm 1.41^{b}$ & $1.38 \pm 0.29^{a b}$ & $18.88 \pm 0.53^{b}$ & $56.65 \pm 1.61^{b}$ & $0.02 \pm 0.02^{\mathrm{a}}$ & $15.20 \pm 1.61^{c}$ \\
\hline
\end{tabular}

Results presented are mean values and the superscripts significantly differ in column $(P<0.05)$.

Sample A: control (durum wheat); Sample B: HCN seed flour; Sample C: HCN seed flour + 0.5\% gum addition; Sample D: HCN seed flour + $1 \%$ gum addition.

Table 6. Cooking properties of pasta.

\begin{tabular}{lccccc} 
Parameters & Sample $(\mathrm{g})$ & Cooking time $(\mathrm{min})$ & Cooked wt. $(\mathbf{g} / \mathbf{1 0 0 g})$ & Solid loss $(\mathbf{g} / \mathbf{1 0 0 g})$ & Water uptake (g/100g) \\
\hline Sample A & 5 & $5.1 \pm 0.20^{\mathrm{a}}$ & $13.49 \pm 0.86^{\mathrm{a}}$ & $6.9 \pm 0.42^{\mathrm{c}}$ & $137 \pm 7.21^{\mathrm{a}}$ \\
Sample B & 5 & $4.2 \pm 0.25^{\mathrm{bc}}$ & $8.57 \pm 0.12^{\mathrm{c}}$ & $16.8 \pm 1.43^{\mathrm{a}}$ & $115 \pm 2.65^{\mathrm{c}}$ \\
Sample C & 5 & $4.5 \pm 0.40^{\mathrm{ac}}$ & $10.30 \pm 0.90^{\mathrm{b}}$ & $10.6 \pm 0.52^{\mathrm{b}}$ & $125 \pm 3.61^{\mathrm{bc}}$ \\
Sample D & 5 & $4.8 \pm 0.56^{\mathrm{ab}}$ & $12.39 \pm 0.38^{\mathrm{a}}$ & $8.13 \pm 0.45^{\mathrm{c}}$ & $132 \pm 6.56^{\mathrm{ab}}$ \\
\hline
\end{tabular}

Sample A: control durum wheat; Sample B: native Horse Chestnut flour; Sample C: 0.5\% gum addition; Sample D: $1 \%$ gum addition. Results presented are mean values and the superscripts significantly differ in column $(P<0.05)(n=6)$.

cooking time, cooked weight, and water uptake increased linearly $(\mathrm{P}<0.05)$ with gum addition in pasta formulation. Results observed are in accordance with findings of Sozer et al. (2007). The enhancement in water uptake with the addition of gum might be related to the accessibility of carboxyl and hydroxyl groups in gum structure, thereby increasing the water uptake of the pasta sample (Gull et al., 2018). In addition, higher water uptake occurs during extended cooking time, as extra water diffuses and interacts with both protein and starch matrices. Besides this, increased affinity for water occurs because of a surge in polar amino-acid groups during cooking owing to protein denaturation (Alonso et al., 2000), leading to subsequent increase in water uptake for pasta. The cooked weight of $\mathrm{HCN}$ pasta samples increased from 9.57/5 g to $12.39 \mathrm{~g} / 5 \mathrm{~g}$ with an increase in the concentration of gum used. The rise in cooked weight may be related to water-binding and water-holding capacity of the gum used for the preparation of pasta (Widelska et al., 2019). Cooking loss is regarded a vital indicator of pasta quality. Cooking loss of pasta samples significantly decreased $(\mathrm{P}<0.05)$ with an increase in the addition of gum concentration from 0 to $1 \%$ in the pasta formulation. The decrease in cooking loss might be due to the addition of guar gum, which improved the protein network, formed a matrix with the proteins where starch granules get entrenched, and thus decreased the tendency of solid loss (Chauhan et al., 2017; Martin-Esparza et al., 2018). HCN pasta made with $1 \%$ gum showed comparable cooking parameters to that of the control sample. For good-quality pasta, an acceptable cooking loss is around 8\% (Dick and Youngs, 1988). Hence, the HCN-flour-based pasta containing $1 \%$ gum has a cooking loss in the acceptable range and could be considered as good quality. A desirable firmness and cooking resistance, low cooking loss, and stickiness are characteristics of high-quality pasta (Lucisano et al., 2012). Studies have shown lowest cooking loss with improved physical and textural properties of gluten-free pasta prepared with $0.6 \%$ of xanthan gum concentration (Milde et al., 2020). Kamsiati and Herawati (2019) observed cooking loss of 5.060\% and hardness of $27.530 \mathrm{~N}$ in cassava macaroni with guar gum addition of $0.25 \%$.

\section{Textural properties of pasta}

The textural assessment of pasta is an important criterion to estimate its quality and acceptance by consumers (Milde et al., 2020). Textural attributes of the developed pasta are presented in Table 7. The use of gum showed significant effects $(P<0.05)$ on the various textural attributes of the tested pasta samples. Firmness of the native HCN pasta sample $(5.44 \mathrm{~N})$ was lower than the control sample $(2.307 \mathrm{~N})$. Moreover, with the addition of gum, the firmness of $\mathrm{HCN}$ pasta samples increased from $2.307 \mathrm{~N}$ to $4.297 \mathrm{~N}$, which might be related to an increase in the binding between protein and starch (Duda et al., 2019). Adhesiveness of $\mathrm{HCN}$ pasta (native) was higher than control pasta while adhesiveness of $\mathrm{HCN}$ pasta prepared with $1 \%$ gum addition was comparable with control. Pasta adhesiveness decreased significantly $(\mathrm{P}<0.05)$ with increased gum concentration in the pasta formulation. The adhesiveness is associated with the amount of starch 
Table 7. Textural properties of cooked pasta.

\begin{tabular}{lrrrr} 
Parameters & \multicolumn{1}{c}{ Sample A } & \multicolumn{1}{c}{ Sample B } & Sample C & Sample D \\
\hline Hardness (N) & $5.44 \pm 0.63^{\mathrm{a}}$ & $2.307 \pm 0.10^{\mathrm{d}}$ & $3.139 \pm 0.22^{\mathrm{c}}$ & $4.297 \pm 0.42^{\mathrm{b}}$ \\
Adhesiveness (Ns) & $-0.390 \pm 0.02^{\mathrm{c}}$ & $-0.202 \pm 0.07^{\mathrm{a}}$ & $-0.354 \pm-0.27^{\mathrm{b}}$ & $-0.398 \pm 0.09^{\mathrm{c}}$ \\
Cohesion & $0.699 \pm 0.07^{\mathrm{a}}$ & $0.470 \pm 0.02^{\mathrm{c}}$ & $0.584 \pm 0.07^{\mathrm{b}}$ & $0.695 \pm 0.08^{\mathrm{a}}$ \\
Springiness \% & $85.572 \pm 2.34^{\mathrm{a}}$ & $53.558 \pm 1.92^{\mathrm{b}}$ & $84.577 \pm 3.45^{\mathrm{a}}$ & $88.060 \pm 3.71^{\mathrm{a}}$ \\
Gumminess & $387.654 \pm 4.23^{\mathrm{a}}$ & $110.460 \pm 3.65^{\mathrm{d}}$ & $187.047 \pm 4.27^{\mathrm{c}}$ & $304.454 \pm 2.81^{\mathrm{b}}$ \\
Chewiness & $331.724 \pm 4.45^{\mathrm{a}}$ & $59.160 \pm 3.45^{\mathrm{d}}$ & $158.199 \pm 2.45^{\mathrm{c}}$ & $268.101 \pm 4.45^{\mathrm{b}}$
\end{tabular}

Sample A: control durum wheat; Sample B: native Horse Chestnut flour; Sample C: $0.5 \%$ gum addition; Sample D: $1 \%$ gum addition. Results presented are mean values and the superscripts significantly differ in row $(P<0.05)(n=6)$.

Table 8. Sensory evaluation of pasta.

\begin{tabular}{lcccc} 
Parameters & Sample A & Sample B & Sample C & Sample D \\
\hline Slipperiness & $3.67^{\mathrm{a}} \pm 0.82$ & $1.83^{\mathrm{c}} \pm 0.98$ & $3.00^{\mathrm{b}} \pm 1.10$ & $3.53^{\mathrm{a}} \pm 1.75$ \\
Firmness & $4.00^{\mathrm{a}} \pm 1.26$ & $1.50^{\mathrm{c}} \pm 0.84$ & $2.50^{\mathrm{b}} \pm 1.22$ & $3.33^{\mathrm{a}} \pm 0.82$ \\
Chewiness & $3.50^{\mathrm{a}} \pm 1.97$ & $2.67^{\mathrm{b}} \pm 1.52$ & $3.00^{\mathrm{a}} \pm 1.51$ & $3.57^{\mathrm{a}} \pm 1.26$ \\
Surface adhesiveness & $3.50^{\mathrm{a}} \pm 1.22$ & $1.13^{\mathrm{c}} \pm 1.03$ & $2.50^{\mathrm{b}} \pm 1.52$ & $3.40^{\mathrm{a}} \pm 1.02$ \\
Appearance & $4.33^{\mathrm{a}} \pm 0.82$ & $2.67^{\mathrm{c}} \pm 1.51$ & $3.17^{\mathrm{b}} \pm 1.60$ & $4.00^{\mathrm{a}} \pm 1.67$ \\
Overall sensory score & $4.5^{\mathrm{a}} \pm 0.26$ & $1.63^{\mathrm{c}} \pm 0.13$ & $2.94^{\mathrm{b}} \pm 0.10$ & $4.43^{\mathrm{a}} \pm 0.17$ \\
\hline
\end{tabular}

Sample A: control durum wheat; Sample B: native Horse Chestnut flour; Sample C: $0.5 \%$ gum addition; Sample D: $1 \%$ gum addition. Mean \pm S.D. with different superscripts in a row differ significantly $(P<0.05)(n=12)$.

and gelatinization of starch. Besides, addition of gum results in the development of continuous protein network, which reduces pasta adhesiveness. Padalino et al. (2013) and Widelska et al. (2019) also observed that the hydrocolloid addition to the gluten-free pasta formulation led to the decrease in adhesiveness. Other textural attributes including cohesiveness, springiness, gumminess, and chewiness also increased with the addition of gum in pasta formulation. Mirhosseini et al. (2015) observed a similar kind of improvement in textural attributes with the addition of polysaccharide gums to gluten-free pasta formulations. HCN-flour-based pasta made with $1 \%$ gum show comparable textural properties with that of the control sample.

\section{Sensory quality of pasta}

The prepared pasta samples were evaluated for appearance, firmness, chewiness, surface adhesiveness, and slipperiness by sensory panellists using a 5-point scale. The mean values of sensory attributes for pasta samples are shown in Table 8 . Sensory score of native $\mathrm{HCN}$ pasta (Sample B) was significantly low compared to control sample (sample A), which could be related to the difference in composition and properties of their corresponding flours (Bolarinwa and Oyesiji, 2021). Among the HCN-flour-based pasta samples, Sample B (0\% gum) showed a minimum score for sensory attributes (appearance, firmness, chewiness, slipperiness, and adhesiveness) while sample D (1\% gum) showed the highest score. No significant difference was observed in the sensory parameters of Sample A (control) and Sample D. Overall, sensory score of Sample D was comparable with that of the control sample. Enhancement in the textural properties of pasta with the addition of gums in pasta formulation led to an improvement in sensory quality. Shere et al. (2020) also observed that gum addition enhanced the overall sensory quality of the developed instant noodles.

\section{Conclusions}

The results provide an insight about the physicochemical, functional, pasting, and thermal properties of HCN flour, and the quality characteristics of pasta made from $\mathrm{HCN}$ flour. The results showed significant difference between the various properties of wheat and HCN flour. Difference in the ratio of flour constituents (protein, starch, etc.) could be the reason for the difference in properties of the two flours. Cooking, textural, and sensory characteristics of HCN-flour-based pasta samples showed that good-quality pasta comparable with commercial 
wheat-based pasta could be prepared from $\mathrm{HCN}$ flour. The study would serve as a template about the derived properties of $\mathrm{HCN}$ flour. Furthermore, gluten-free pasta could be made from HCN flour using appropriate proportion of gum in the production process. In addition, the study suggests that $\mathrm{HCN}$ flour could be used as a substitute for conventional flours for the development of gluten-free pasta. Further research should be carried out to determine the possible utilization of $\mathrm{HCN}$ flour in the development of other food products.

\section{Acknowledgments}

The first author is thankful to the UGC for Maulana Azad National Fellowship.

\section{Conflict of Interest}

The authors state no conflict of interest.

\section{References}

AACC, 2000. Approved methods of the American Association of Cereal Chemistry, American Association of Cereal Chemists Inc., St. Paul, MN.

Abu, J.O., Duodu, K.G. and Minnaar, A., 2006. Effect of $\gamma$-irradiation on some physicochemical and thermal properties of cowpea (Vigna unguiculata L. Walp) starch. Food Chemistry 95(3): 386-393. https://doi.org/10.1016/j.foodchem.2005. 01.008

Adebowale, K.O. and Lawal, O.S., 2004. Comparative study of the functional properties of bambarra groundnut (Voandzeia bean subterranean), jack (Canavalia ensiformis) and mucuna bean (Mucuna pruriens) flours. Food Research International 37(4): 355-365. https://doi.org/10.1016/j.foodres.2004.01.009

Adebowale, Y.A., Adeyemi, I.A. and Oshodi, A.A., 2005. Functional and physicochemical properties of flours of six Mucuna species. African Journal of Biotechnology 4(12): 1461-1468.

Al-Farga, A., Zhang, H., Siddeeg, A., Shamoon, M., Chamba, M.V. and Al-Haji, N., 2016. Proximate composition, functional properties, amino acid, mineral and vitamin contents of a novel food: Alhydwan (Boerhavia elegana Choisy) seed flour. Food chemistry. 211: 268-273. https://doi.org/10.1016/j. foodchem.2016.05.016

Alonso, R., Aguirre, A. and Marzo, F., 2000. Effects of extrusion and traditional processing methods on antinutrients and in vitro digestibility of protein and starch in faba and kidney beans. Food Chemistry 68(2): 159-165. https://doi.org/10.1016/ S0308-8146(99)00169-7

AOAC, 2006. Official methods of analysis, 18th ed., Association of Official Analytical Chemists, AOAC Press, Gaithersburg, MD.

Bolarinwa, I.F. and Oyesiji, O.O., 2021. Gluten free rice-soy pasta: proximate composition, textural properties, and
sensoryattributes.Heliyon 7(1):e06052.https://doi.org/10.1016/j. heliyon.2021.e06052

Bresciani, A., Giordano, D., Vanara, F., Blandino, M. and Marti, A., 2021. High-amylose corn in gluten-free pasta: strategies to deliver nutritional benefits ensuring the overall quality. Food Chemistry 353: 129489. https://doi.org/10.1016/j. foodchem.2021.129489

Çabuk, B. and Yllmaz, B., 2020. Fortification of traditional egg pasta (erişte) with edible insects: nutritional quality, cooking properties and sensory characteristics evaluation. Journal of Food Science and Technology 57(7): 2750-2757. https://doi. org/10.1007/s13197-020-04315-7

Cai, J., Chiang, J.H., Tan, M.Y.P., Saw, L.K., Xu, Y. and NganLoong, M.N., 2016. Physicochemical properties of hydrothermally treated glutinous rice flour and xanthan gum mixture and its application in gluten-free noodles. Journal of Food Engineering 186: 1-9. https://doi.org/10.1016/j.jfoodeng.2016.03.033

Capriles, V.D., dos Santos, F.G. and Arêas, J.A.G., 2016. Gluten-free breadmaking: improving nutritional and bioactive compounds. Journal of Cereal Science 67: 83-91. https://doi.org/10.1016/j. jcs.2015.08.005

Chauhan, A., Saxena, D.C. and Singh, S., 2017. Effect of hydrocolloids on microstructure, texture and quality characteristics of glutenfree pasta. Journal of Food Measurement and Characterization 11: 1188-1195. https://doi.org/10.1007/ s11694-017-9495-4

Chau, C.F., Cheung, P.C. and Wong, Y.S., 1997. Functional properties of protein concentrates from three Chinese indigenous legume seeds. Journal of Agricultural and Food Chemistry. 45(7):2500-2503. https://doi.org/10.1021/jf970047c

Chauvin, E.A., 2019. Health and wellness series-nutrition and women's health global analysis report. Agriculture and Agri-Food Canada. Available at: http://www.agr.gc.ca/eng/ industrymarkets-and-trade/international-agri-food-marketintelligence/reports/health-and-wellnessseries-nutrition-andwomen-s-health/?id=1546614914143.

Dib, A., Wójtowicz, A., Benatallah, L., Zidoune, M.N., Mitrus, M. and Sujak, A., 2018. Optimization of rice-field bean gluten-free pasta improved by the addition of hydrothermally treated rice flour. Italian Journal of Food Science 30(2): 226-248

Dick, J.W. and Youngs, V.L., 1988. Evaluation of durum wheat, semolina, and pasta in the United States. Available at: https://agris. fao.org/agris-search/search.do?recordID=US1989010334.6.

Drakos, A., Kyriakakis, G., Evageliou, V., Protonotariou, S., Mandala, I. and Ritzoulis, C., 2017. Influence of jet milling and particle size on the composition, physicochemical and mechanical properties of barley and rye flours. Food Chemistry 215: 326-332. https://doi.org/10.1016/j.foodchem.2016.07.169

Du, S.K., Jiang, H., Yu, X. and Jane, J.L., 2014. Physicochemical and functional properties of whole legume flour. LWTFood Science and Technology 55(1): 308-313. https://doi. org/10.1016/j.lwt.2013.06.001

Duda, A., Adamczak, J., Chełmińska, P., Juszkiewicz, J. and Kowalczewski, P., 2019. Quality and nutritional/textural properties of durum wheat pasta enriched with cricket powder. Foods 8(2): 46. https://doi.org/10.3390/foods 802004.6 
Foschia, M., Beraldo, P. and Peressini, D., 2017. Evaluation of the physicochemical properties of gluten-free pasta enriched with resistant starch. Journal of the Science of Food and Agriculture 97(2): 572-577. https://doi.org/10.1002/jsfa.7766

Fuad, T. and Prabhasankar, P., 2010. Role of ingredients in pasta product quality: a review on recent developments. Critical Reviews in Food Science and Nutrition 50(8): 787-798. https:// doi.org/10.1080/10408390903001693

Gull, A., Prasad, K. and Kumar, P., 2018. Nutritional, antioxidant, microstructural and pasting properties of functional pasta. Journal of the Saudi Society of Agricultural Sciences 17(2): 147153. https://doi.org/10.1016/j.jssas.2016.03.002

Hager, A.S., Wolter, A., Jacob, F., Zannini, E. and Arendt, E.K., 2012. Nutritional properties and ultra-structure of commercial gluten free flours from different botanical sources compared to wheat flours. Journal of Cereal Science 56(2): 239-247. https://doi. org/10.1016/j.jcs.2012.06.005

Jia, J., Ji, B., Tian, L., Li, M., Lu, M., Ding, L., Liu, X. and Duan, X., 2021. Mechanism study on enhanced foaming properties of individual albumen proteins by Lactobacillus fermentation. Food Hydrocolloids. 111: 106218. https://doi.org/10.1016/j. foodhyd.2020.106218

Joshi, A.U., Liu, C. and Sathe, S.K., 2015. Functional properties of select seed flours. LWT-Food Science and Technology 60(1): 325-331. https://doi.org/10.1016/j.lwt.2014.08.038

Kamsiati, E. and Herawati, H., 2019. Influence of glycerol mono stearate and guar gum on quality characteristics of gluten free macaroni from cassava. IOP Conference Series: Earth and Environmental Science 309(1): 012029. https://doi. org/10.1088/1755-1315/309/1/012029

Kaur, G., Sharma, S., Nagi, H.P.S. and Dar, B.N., 2012. Functional properties of pasta enriched with variable cereal brans. Journal of Food Science and Technology 49: 467-474. https://doi. org/10.1007/s13197-011-0294-3

Kaur, L., Joseph, L. and George, M., 2011. Phytochemical analysis of leaf extract of Aesculus indica. International Journal of Pharmacy and Pharmaceutical Sciences 3(5): 232-234.

Kaur, M. and Sing,h N., 2005. Studies on functional, thermal and pasting properties of flours from different chickpea (Cicer arietinum L.) cultivars. Food Chemistry 91(3): 403-411. https://doi. org/10.1016/j.foodchem.2004.06.015

Khan, A. and Saini, C.S., 2016. Effect of roasting on physicochemical and functional properties of flaxseed flour. Cogent Engineering 3(1): 1145566. https://doi.org/10.1080/23311916.2016.1145566

Khattab, R.Y. and Arntfield, S.D., 2009. Functional properties of raw and processed canola meal. LWT-Food Science and Technology 42(6): 1119-1124. https://doi.org/10.1016/j. lwt.2009.02.009

Kumar, C.M., Sabikhi, L., Singh, A.K., Raju, P.N., Kumar, R. and Sharma, R., 2019. Effect of incorporation of sodium caseinate, whey protein concentrate and transglutaminase on the properties of depigmented pearl millet based gluten free pasta. LWT 103: 19-26. https://doi.org/10.1016/j.lwt.2018.12.071

Lazaridou, A., Duta, D., Papageorgiou, M., Belc, N. and Biliaderis, C.G., 2007. Effects of hydrocolloids on dough rheology and bread quality parameters in gluten-free formulations.
Journal of Food Engineering 79(3): 1033-1047. https://doi. org/10.1016/j.jfoodeng.2006.03.032

Leewatchararongjaroen, J. and Anuntagool, J., 2016. Effects of dry-milling and wet-milling on chemical, physical and gelatinization properties of rice flour. Rice Science 23(5): 274-281. https://doi.org/10.1016/j.rsci.2016.08.005

Lorenzo, G., Sosa, M. and Califano, A., 2018. Alternative proteins and Pseudocereals in the development of gluten-free pasta. In: Alternative and replacement foods, Editor(s): Holban, A.M., and Grumezescu, A.M. Academic Press, Cambridge, Massachusetts. pp. 433-458. https://doi.org/10.1016/ B978-0-12-811446-9.00015-0

Lucisano, M., Cappa, C., Fongaro, L. and Mariotti, M., 2012. Characterisation of gluten-free pasta through conventional and innovative methods: evaluation of the cooking behaviour. Journal of Cereal Science 56(3): 667-675. https://doi. org/10.1016/j.jcs.2012.08.014

Majeed, M., Khan, M.A., Bashir, A. and Hussain, A., 2010. Nutritional value and oil content of Indian Horse-Chestnut seed. Global Journal of Science Frontier Research 10(4): 17-19.

Martin-Esparza, M.E., Raigon, M.D., Raga, A. and Albors, A., 2018. High fibre tiger nut pasta and xanthan gum: cooking quality, microstructure, physico-chemical properties and consumer acceptance. Food Science and Biotechnology 27(4): 1075-1084. https://doi.org/10.1007/s10068-018-0341-1

Milde, L.B., Chigal, P.S., Olivera, J.E. and González, K.G., 2020. Incorporation of xanthan gum to gluten-free pasta with cassava starch. Physical, textural, and sensory attributes. LWT-Food Science Technology 131: 109674. https://doi.org/10.1016/j. lwt.2020.109674

Mirhosseini, H., Rashid, N.F.A., Amid, B.T., Cheong, K.W., Kazemi, M. and Zulkurnain, M., 2015. Effect of partial replacement of corn flour with durian seed flour and pumpkin flour on cooking yield, texture properties, and sensory attributes of gluten free pasta. LWT-Food Science and Technology 63(1): 184-190. https://doi.org/10.1016/j.lwt.2015.03.078

Njintang, Y.N., Scher, J. and Mbofung, C.M.F., 2008. Physicochemical, thermal properties and microstructure of six varieties of taro (Colocasia esculenta L. Schott) flours and starches. Journal of Food Engineering 86(2): 294-305. https:// doi.org/10.1016/j.jfoodeng.2007.10.006

Ocheme, O.B., Adedeji, O.E., Chinma, C.E., Yakubu, C.M. and Ajibo, U.H., 2018. Proximate composition, functional, and pasting properties of wheat and groundnut protein concentrate flour blends. Food Science \& Nutrition 6(5): 1173-1178. https://doi. org/10.1002/fsn3.670

Ofori, J., Tortoe, C. and Agbenorhevi, J.K., 2020. Physicochemical and functional properties of dried okra (Abelmoschus esculentus L.) seed flour. Food Science \& Nutrition 8(8): 42914296. https://doi.org/10.1002/fsn3.1725

Ozgoren, E. and Yapar, A., 2019. Effect of the addition of smoked trout fillet powder to the quality properties of pasta. Italian Journal of Food Science 31(1): 110-124.

Padalino, L., Conte, A. and Del Nobile, M.A., 2016. Overview on the general approaches to improve gluten-free pasta and bread. Foods 5(4): 87. https://doi.org/10.3390/foods504.0087 
Padalino, L., Lecce, L., Cozzolino, F. and Del Nobile, M.A., 2013. Manufacture and characterization of gluten-free spaghetti enriched with vegetable flour. Journal of Cereal Science 57(3): 333-342. https://doi.org/10.1016/j.jcs.2012.12.010

Palavecino, P.M., Bustos, M.C., Heinzmann Alabí, M.B., Nicolazzi, M.S., Penci, M.C. and Ribotta, P.D., 2017. Effect of ingredients on the quality of gluten-free sorghum pasta. Journal of Food Science 82(9): 2085-2093. https://doi.org/10.1111/1750-3841.13821

Pasqualone, A., Gambacorta, G., Summo, C., Caponio, F., Di Miceli, G., Flagella, Z., et al., 2016. Functional, textural and sensory properties of dry pasta supplemented with lyophilized tomato matrix or with durum wheat bran extracts produced by supercritical carbon dioxide or ultrasound. Food chemistry. 213: pp. 545-553. https://doi.org/10.1016/j.foodchem.2016.07.006

Petitot, M., Boyer, L., Minier, C. and Micard, V., 2010. Fortification of pasta with split pea and faba bean flours: pasta processing and quality evaluation. Food Research International 43(2): 634-641. https://doi.org/10.1016/j.foodres.2009.07.020

Phongthai, S., D’Amico, S., Schoenlechner, R., Homthawornchoo, W. and Rawdkuen, S., 2017. Effects of protein enrichment on the properties of rice flour-based gluten-free pasta. LWT 80: 378385. https://doi.org/10.1016/j.lwt.2017.02.044

Rafiq, S.I., Singh, S. and Saxena, D.C., 2016. Physical, physicochemical and anti-nutritional properties of Horse Chestnut (Aesculus indica) seed. Journal of Food Measurement and Characterization 10(2): 302-310. https://doi.org/10.1007/s11694-016-9307-2

Raigar, R.K. and Mishra, H.N., 2015. Effect of moisture content and particle sizes on physical and thermal properties of roasted Bengal gram flour. Journal of Food Processing and Preservation 39(6): 1839-1844. https://doi.org/10.1111/jfpp.12419

Rajasekaran, A. and Joginder, S., 2009. Ethnobotany of Indian horse chestnut (Aesculus indica) in Mandi district, Himachal Pradesh. Indian Journal of Traditional Knowledge 8(2): 285-286. Available at: https://www.cabdirect.org/cabdirect/ abstract/20093162490.

Ravi, R. and Susheelamma, N.S., 2005. Simultaneous optimization of a multi-response system by desirability function analysis of boondi-making: a case study. Journal of Food Science 70(8): s539-s547. https://doi.org/10.1111/j.1365-2621.2005.tb11531

Rincón-Londoño, N., Millan-Malo, B. and Rodríguez-García, M.E., 2016. Analysis of thermal pasting profile in corn starch rich in amylose and amylopectin: physicochemical transformations, part II. International Journal of Biological Macromolecules 89: 43-53. https://doi.org/10.1016/j.ijbiomac.2016.04.057

Rudra, S.G., Anand, V., Kaur, C., Bhooshan, N. and Bhardwaj, R., 2020. Hydrothermal treatment to improve processing characteristics of flour for gluten-free pasta. Starch-Stärke 72: 9-10, 1900320. https://doi.org/10.1002/star.201900320

Shere, P.D., Sahni, P., Devkatte, A.N. and Pawar, V.N., 2020. Influence of hydrocolloids on quality characteristics, functionality and microstructure of spinach puree-enriched instant noodles. Nutrition \& Food Science 50: 1568-1577. https://doi. org/10.1108/NFS-10-2019-0318

Shevkani, K., Kaur, A., Kumar, S. and Singh, N., 2015. Cowpea protein isolates: functional properties and application in gluten-free rice muffins. LWT-Food Science and Technology. 63(2): 927933. https://doi.org/10.1016/j.lwt.2015.04.058

Siddiq, M., Ravi, R., Harte, J.B. and Dolan, K.D., 2010. Physical and functional characteristics of selected dry bean (Phaseolus vulgaris L.) flours. LWT-Food Science Technology 43(2): 232237. https://doi.org/10.1016/j.lwt.2009.07.009

Simonato, B., 2021. Improving the sensory, nutritional and technological profile of conventional and gluten-free pasta and bakery products. Foods. 10(5): 975. https://doi.org/10.3390/ foods10050975

Singh, G.D., Singh, S., Jindal, N., Bawa, A.S. and Saxena, D.C., 2010. Physico-chemical characteristics and sensory quality of Singhara (Trapa natans L.): an Indian water chestnut under commercial and industrial storage conditions. African Journal of Food Science 4(11): 693-702. https://doi.org/10.5897/AJFS.9000228

Singh, N., Kaur, A., Katyal, M., Bhinder, S., Ahlawat, A.K. and Singh, A.M., 2016. Diversity in quality traits amongst Indian wheat varieties II: paste, dough and muffin making properties. Food Chemistry 197: 316-324. https://doi.org/10.1016/j. foodchem.2015.10.035

Singh, N., Shevkani, K., Kaur, A., Thakur, S., Parmar, N. and Singh Virdi, A., 2014. Characteristics of starch obtained at different stages of purification during commercial wet milling of maize. Starch-Stärke 66: 668-677. https://doi.org/10.1002/star.201300261

Singh, S., Riar, C.S. and Saxena, D.C., 2013. Effect of incorporating sweetpotato flour to wheat flour on the quality characteristics of cookies. African Journal of Food Science 2(6): 65-72. https:// doi.org/10.5897/AJFS.9000089

Sozer, N., Dalgic, A.C. and Kaya, A., 2007. Thermal, textural and cooking properties of spaghetti enriched with resistant starch. Journal of Food Engineering 81(2): 476-484. https://doi. org/10.1016/j.jfoodeng.2006.11.026

Sreerama, Y.N., Sashikala, V.B., Pratape, V.M. and Singh, V., 2012. Nutrients and antinutrients in cowpea and horse gram flours in comparison to chickpea flour: evaluation of their flour functionality. Food Chemistry 131(2): 462-468. https://doi.org/10.1016/j. foodchem.2011.09.008

Teterycz, D., Sobota, A., Zarzycki, P. and Latoch, A., 2020. Legume flour as a natural colouring component in pasta production. Journal of Food Science and Technology 57(1): 301-309. https:// doi.org/10.1007/s13197-019-04061-5

Vázquez-Luna, A., Fuentes Carmona, F.F., Rivadeneyra, E., Hernández, C. and Diaz-Sobac, R., 2019. Nutrimental content and functional properties of Quinoa flour from Chile and Mexico. Ciencia e Investigación Agraria 46(2): 144-153. https:// doi.org/10.7764/rcia.v46i2.2099

Widelska, G., Wójtowicz, A., Kasprzak, K., Dib, A., Oniszczuk, T., Olech, M., et al. 2019. Impact of xanthan gum addition on phenolic acids composition and selected properties of new glutenfree maize-field bean pasta. Open Chemistry 17(1): 587-598. https://doi.org/10.1515/chem-2019-0075

Witczak, T., Juszczak, L., Ziobro, R. and Korus, J., 2017. Rheology of gluten-free dough and physical characteristics of bread with potato protein. Journal of Food Process Engineering 40(3): e12491. https://doi.org/10.1111/jfpe.12491 
Xu, M., Jin, Z., Simsek, S., Hall, C., Rao, J. and Chen, B., 2019. Effect of germination on the chemical composition, thermal, pasting, and moisture sorption properties of flours from chickpea, lentil, and yellow pea. Food Chemistry 295: 579-587. https://doi. org/10.1016/j.foodchem.2019.05.167

Yan, X., Ma, C., Cui, F., McClements, D.J., Liu, X. and Liu, F., 2020. Protein-stabilized pickering emulsions: formation, stability, properties, and applications in foods. Trends in Food Science and Technology 103: 293-303. https://doi.org/10.1016/j. tifs.2020.07.005

Yu, S., Ma, Y., Menager, L. and Sun, D.W., 2012. Physicochemical properties of starch and flour from different rice cultivars. Food and Bioprocess Technology 5(2): 626-637. https://doi. org/10.1007/s11947-010-0330-8 